\title{
First report of blossom blight caused by Cladosporium cladosporioides on Dendrobium phalaenopsis in Malaysia
}

\author{
Siti Izera Ismail ${ }^{1,2}$ (D) Siti Nur Rosmawatie Pauzei ${ }^{1}$
}

Received: 18 September 2021 / Accepted: 15 October 2021 / Published online: 26 October 2021

(c) Società Italiana di Patologia Vegetale (S.I.Pa.V.) 2021

Keywords Cladosporium cladosporioides · Orchid · Blossom blight · Dendrobium phalaenopsis

In March 2020, orchid (Dendrobium phalaenopsis) showing blossom blight symptoms (approximately 60\% disease incidence) were observed in an orchid greenhouse in Banting province, Selangor, Malaysia. Symptoms appeared as dark necrotic lesion on the column, and affected inflorescences wilted and eventually flowers abscised. Symptomatic tissues were surface-sterilized by $70 \%$ ethanol, rinsed with sterile distilled water, and plated on PDA medium. The colonies produced grey-olivaceous, sparse aerial mycelium with a velvety texture. Conidia were single-celled, aseptate, and elliptical in shape developed on branched chains, 3 to $12 \mu \mathrm{m} \times 3$ to $5 \mu \mathrm{m}(n=40)$. Six isolates with similar morphological characteristics to Cladosporium cladosporioides (Bensch et al. 2012) were obtained from tissue samples. PCR was performed using the EF1-728F/ EF1-986R for translation elongation factor (Carbone and Kohn 1999) and ITS5/ITS4 for rDNA (White et al. 1990) followed by sequencing three representative isolates $(\mathrm{O} 1$, $\mathrm{O} 2$, and $\mathrm{O} 3$ ). The sequences were deposited in the GenBank (TEF: OK166821, OK166822, OK166823; ITS: OK149111, OK149112, OK149113). A phylogenetic analysis using maximum likelihood inference was performed using published ITS and TEF sequence dataset for Cladosporium species. Isolates $\mathrm{O} 1, \mathrm{O} 2$ and $\mathrm{O} 3$ grouped in a strongly supported clade (100\% bootstrap) with ex-type cultures of $C$. cladosporioides. Pathogenicity tests were conducted on five 3-month-old orchid plants grown in the greenhouse at $28{ }^{\circ} \mathrm{C}, 95 \%$ relative humidity with a 12 -h photoperiod. The

Siti Izera Ismail

izera@upm.edu.my

1 Department of Plant Protection, Faculty of Agriculture, Universiti Putra Malaysia, 43400 Serdang, Selangor, Malaysia

2 Laboratory of Climate-Smart Food Crop Production, Institute of Tropical Agriculture and Food Security (ITAFoS), Universiti Putra Malaysia, 43400 Serdang, Selangor, Malaysia inflorescences were inoculated by a conidia suspension $\left(10^{6}\right.$ conidia/ml) of each isolate. Six control inflorescences were sprayed with sterile distilled water as a control. After twelve days, similar symptoms to those observed in the greenhouse appeared on the inoculated inflorescences, while control inflorescences were asymptomatic. The pathogen was reisolated from symptomatic inflorescences and morphologically and molecularly identified as $C$. cladosporioides. The reference isolate $\mathrm{O} 1$ was deposited in the Microbial Collection Unit, UPM, with accession number MCU-O1. To our knowledge, this is the first report of blossom blight on orchid caused by $C$. cladosporioides in Malaysia.

Supplementary information The online version contains supplementary material available at https://doi.org/10.1007/s42161-021-00986-z.

\section{Declarations}

Ethical statement This article does not contain any studies with human participants or animals.

Conflict of interest All authors declare that they have no confict of interests.

\section{References}

Bensch K, Braun U, Groenewald JZ, Crous PW (2012) The genus Cladosporium. Stud Mycol 72:1-401

Carbone I, Kohn LM (1999) A method for designing primer sets for speciation studies in filamentous ascomycetes. Mycologia 91:553-556

White TJ, Bruns T, Lee S, Taylor J (1990) Amplification and direct sequencing of fungal ribosomal RNA genes for phylogenetics. In: Innis MA, Gelfand DH, Sninsky JJ, White TJ (eds) PCR Protocols a Guide to Methods and Applications. Academic Press, San Diego, CA, USA, pp 315-322

Publisher's Note Springer Nature remains neutral with regard to jurisdictional claims in published maps and institutional affiliations. 